\title{
Assessment of Aero-radiometric Data of Southern Anambra Basin for the Prospect of Radiogenic Heat Production
}

\section{*11 KUFORIJIMI, OLORUNSOLA; ${ }^{1}$ CHRISTOPHER, AIGBOGUN}

\author{
${ }^{I}$ Department of Physics, University of Benin, Benin City \\ Corresponding author E-mail: kuforijimi@gmail.com
}

\begin{abstract}
High-resolution aero-radiometric data from three radio-elements (Uranium, Potassium and Thorium) were used and processed independently to investigate the Southern Anambra basin for the prospect of producing radiogenic heat. The rock types in the study area were outlined while processing the elements in each rock to evaluate the radiogenic heat production values. The results of the analysis of the radiogenic heat production of the study area ranges between $0.01-5.43 \mu \mathrm{Wm}^{-3}$. The highest heat produced came from the sedimentary rocks (Shale) with radiogenic heat production value up to $5.43 \mu \mathrm{Wm}^{-3}$. The highest value of the radiogenic heat production in this basin has a value of $5.43 \mu \mathrm{Wm}^{-3}$ around Aimeke and Ogobia. The airborne total radiometric count of radio-elements and radiogenic heat maps were produced. (C) JASEM https://dx.doi.org/10.4314/jasem.v21i4.15
\end{abstract}

Key Words: Aero-radiometric; Radiogenic Heat; Anambra Basin; Geothermal

Anambra basin has not really been subjected to detailed radiogenic heat production despite the geological features that suggest that the area has prospect for geothermal energy production. This research focuses on locating radiogenic heat hotspot in this basin where geothermal plant can be sited and to know if there are no anomalous heat productions. The radiogenic heat map was interpreted and to know the productive area based on the geographic projection of the locations on the map. The digitized and georeferenced geological map of the study area outlined rock unit boundaries that were present in the study area for easy identification and assigning rock unit densities. The need for comprehensive geothermal potentials stimulates this research work and to locate geothermal reservoir in Anambra basin to add to energy needs of Nigeria. Also, the paucity of information and knowledge on the existing and potential effects of geothermal energy and radiogenic heat production in Nigeria justifies this research. Apart from geothermal energy, radiogenic heat production can be used for other purposes like; interpretation of existing heat flow variations and explanation of temperature variations with depth. It can also be used for making heat flow or heat production measurements (Megwara et al., 2012; Salem et al., 2005). Although radioactive decay of rocks is probably the greatest overall source of heat in the Earth's crust by a substantial factor, there are other sources that may be peculiar to specific area (Salem et al., 2005; Jessop, 1990). Rocks with high radiogenic heat production are usually focused on for geothermal energy exploration. This study covers the processing of aero-radiometric data to obtain the radio-elements present in the study area, carrying out qualitative, quantitative analysis and interpretation of the radiogenic heat map to determine the radioelement mineralization, Production of a Ternary map and to locate productive area for geothermal energy and radiogenic heat production.

\section{MATERIALS AND METHODS}

Geological Background of the Study Area: The area of study is bounded by latitudes $7^{\circ} 00^{\prime}$ and $9^{\circ} 00^{\prime}$ North and longitudes $6^{\circ} 00^{\prime}$ and $7^{\circ} 30^{\prime}$ East of the Southern part of Anambra basin and covers an area of approximately 33,708 Sq-Km. The Anambra basin (also known as the Lower Benue Trough) is an elongated NE - SW trends as marked out in Figure 1 and is located at the south-western fringe of the Benue Trough bordered on the west by the Precambrian basement complex rocks of western Nigeria and on the east by the Abakaliki Anticlinorium. Sedimentation in the Lower Benue Trough started with the marine Albian Asu River Group, even though some pyroclastics of Aptian Early Albian ages have been scarcely reported (Ojoh, 1992). The Asu River Group in the Lower Benue Trough consists of shales, limestones and sandstone lenses of the Abakaliki Formation in the Abakaliki area and the Mfamosing Limestone in the Calabar Flank (Petters, 1982). 


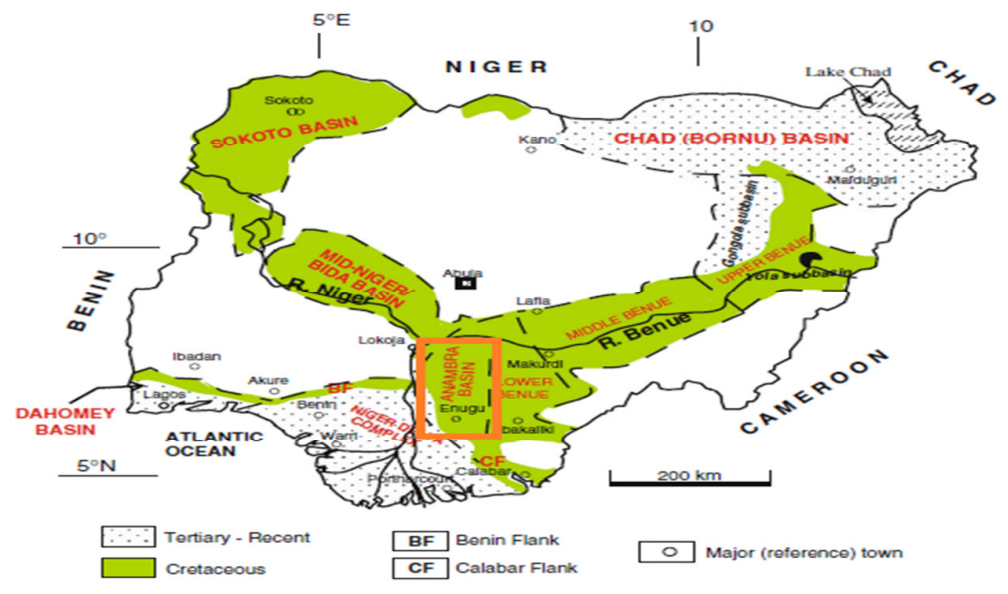

Fig 1: Map of Sedimentary basin of Nigeria showing the study area in the red rectangle (Source: Obaje, 2009).

Acquisition of Aero-radiometric Data: A very high quality Twelve (12) sheets of aero-radiometric data that cover the study area were acquired from Nigerian Geological Survey Agency, Abuja (NGSA), which carried out airborne radiometric survey of Nigeria between the years 2002 - 2009. The Twelve (12) maps are numbered: $268-271,287-290 \& 301-$ 304. The data obtained from the airborne survey was presented in digital form as a composite grid of $1: 100,000$ sheets covering the study area. The aeroradiometric data were acquired at a flight elevation of $80 \mathrm{~m}$, line spacing and tie-line spacing were $500 \mathrm{~m}$ and $5000 \mathrm{~m}$ respectively. A line direction of $135 / 315$ degrees was accepted for the survey. The aeroradiometric data for this study was gotten by cropping out 12 aero-radiometric sheets for processing and accurate interpretation of radiogenic heat values. The gridded data were fed into a geospatial software called "Oasis Montaj" to process each radio-element. The three-elements were combined to form a total count map and rock unit boundaries were clearly separated by geo-referencing and digitizing the geological map of the study area in order to show each rock unit present and the concentration of radioelements.

Radiogenic Heat Production: The radiogenic heat analysis was carried out using calculation of ratios from the three radio-elements: Uranium (ppm), Thorium (ppm) and Potassium (\%). The method applied is similar to that of (Salem et al., 2005) and (Megwara et al., 2012) who also did something similar but different processing method. In the previous studies, radiogenic heat production was calculated from concentrations of radio-elements measured in the laboratory by (Fernández, et al., 1998) and directly from gamma-ray log by (Bücker and Rybach, 1996) in order to get the accurate radiogenic heat values. Also, radiogenic heat production was assessed from airborne gamma-ray data (Salem et al., 2005, 1980; Thompson et al., 1996). In this research, radiogenic heat production was calculated from aero-radiometric data. For comprehensive evaluation of radiogenic heat production from aero-radiometric data, the rock unit type present in the study area and their boundaries were well outlined for accurate results and interpretation. The southern part of Anambra basin contains both sedimentary and igneous rocks which have been identified on the geological/mineral map of the study area (Figure 2). The radiogenic heat values were calculated from the energy released from the Alpha, Beta and Gamma decay of rocks (Salem and Fairhead, 2011) and using an empirical equation by Rybach (1976) as expressed below:

$\mathrm{A}\left(\mu \mathrm{W} / \mathrm{m}^{3}\right)=\rho\left(0.0952 \mathrm{C}_{\mathrm{u}}+0.0256 \mathrm{C}_{\mathrm{Th}}+0.0348 \mathrm{C}_{\mathrm{k}}\right)$ (1)

where $A$ is the radiogenic heat, $\rho$ is the density of rock

$\mathrm{C}_{\mathrm{u}}, \mathrm{C}_{\mathrm{Th}}$ and $\mathrm{C}_{\mathrm{k}}$ are the concentrations of Uranium (ppm), Thorium (ppm) and Potassium (\%) respectively.

Based on the Rybach equation (1) above, Uranium produces the highest heat during radiogenic heat decay of the radio-elements and its constant value is twice more than that of Potassium and Thorium. The individual concentration of the three radio-elements is obtained from the radiogenic map covering the study area. The value of each radio-element's concentration is applied in equation (1) to calculate the radiogenic heat production for the individual rock type outlined in the geological map (Figure 2). 


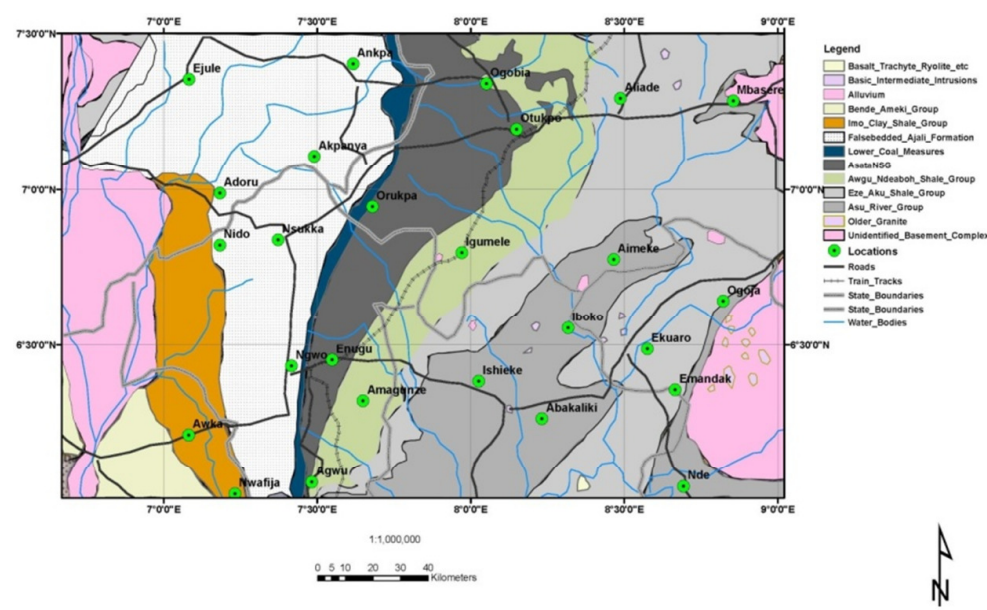

Fig 2: Geological and Mineral map of the study area (Adapted from Geological and Mineral Map of Nigeria, 2009, Nigerian Geological Survey Agency). x-y axes are longitude and latitude coordinates.

\section{RESULTS AND DISCUSSIONS}

Total Radiometric Anomalies Count Map of the Study Area: The total count of the three radio-elements (Uranium (ppm), Thorium (ppm) and Potassium (\%)) is presented as a map (Figure 3) with a total count of about $472.4 \mathrm{cpt}-2727.7 \mathrm{cpt}$ map of the study area. The map shows high concentration of total count values in parts of the study area mostly around Ogobia, Aimeke, Mbashere and Nde. There is low concentration of total count values around Ankpa, Ngwo and Akoanya area.

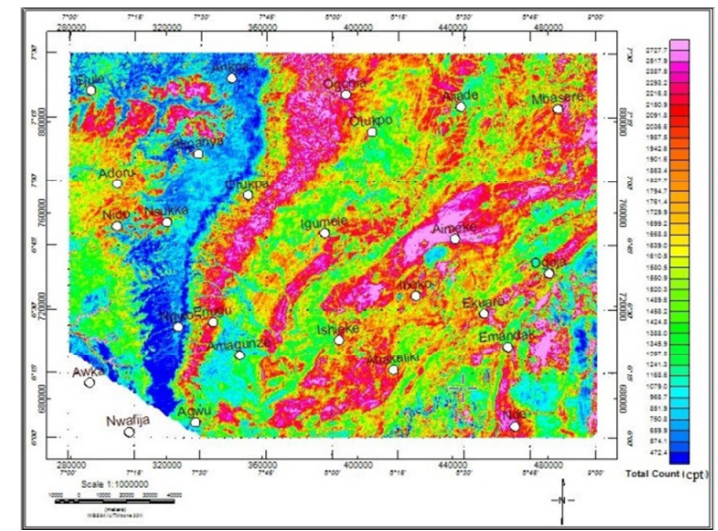

Fig 3: Total Airborne Radiometric Anomalies count map of the study area. The $\mathrm{x}$ - $\mathrm{y}$-axes are longitude and latitude coordinates in decimal degrees.

Ternary Map of the Study Area: The triangular plot of the radio-elements showed in figure 4 displays a ternary image by combining the three radio-elements. Largely, ternary plots of the radio-elements usually give a superior image of the geology (Salem et al., 2005). This can be seen in the good correlation between the ternary image (Figure 3) and the mapped geology (Figure 4). The isolated radio-element as shown in the ternary map is also useful to classify some rock types. 


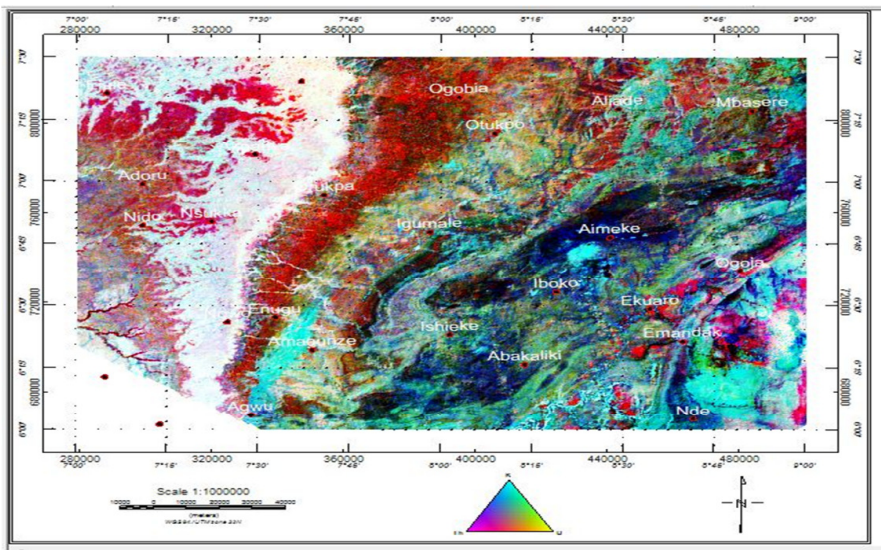

Fig 4: Ternary image constructed from the Radio elements (K (\%), eU, and eTh) maps. The $\mathrm{x}-\mathrm{y}$-axes are longitude and latitude coordinates in decimal degrees.

Qualitative and Quantitative Analysis of the Radiogenic Heat Production: The following thirteen rock units: Unidentified Basement Complex, Granite, Asu River Group, Eze Aku Group, Awgu Ndeaboh Shale Group, Asata Nkporo Group, Lower Coal Measures, False bedded Sandstones, Bende Ameki Group, Imo Clay -Shale Group, Alluvium, Basic and Intermediate Intrusions and Basalt Trachyte Rhyolite were identified and assigned for further calculation of the radiogenic heat production based on the concentrations of potassium, thorium and uranium within each rock unit. The boundary of each rock unit was outlined in Figure 2 and the concentrations of radio-elements $(\mathrm{K}(\%)$, eU, and $\mathrm{eTh})$ within each rock unit were separated.

The summary of the results of the analysis of radiogenic heat value for each rock unit is presented in Table 1 and illustrated as map in Figure 5 as radiogenic heat production map of the study area. High heat concentrations were observed around Ameki, Iboko, Mbashere, Ogobia and Nde. Radiogenic heat production values for each rock unit were calculated based on Equation (1).

Table 1: Radiogenic heat production corresponding to each rock unit (in $\mu \mathrm{Wm}^{-3}$ )

\begin{tabular}{llll}
\hline Rock Units & Minimum & $\begin{array}{c}\text { Range } \\
\text { Maximum }\end{array}$ & Average \\
& 0.53 & 2.75 & \\
Basalt Trachyte Ryolite & 0.73 & 3.26 & 1.75 \\
Basic Intermediate Intrusion & 0.16 & 2.76 & 2.29 \\
Alluvium & 0.06 & 2.35 & 1.11 \\
Bende Ameki Group & 0.17 & 2.10 & 0.45 \\
Imo Clay Measures & 0.09 & 3.26 & 0.91 \\
False bedded Ajali Formation & 0.03 & 2.09 & 0.79 \\
Lower Coal Measures & 0.01 & 5.43 & 0.95 \\
AsataNkporo Shale & 0.01 & 4.96 & 2.47 \\
AwguNdeaboh Shale Group & 0.03 & 3.85 & 2.06 \\
EzeAku Shale Group & 0.02 & 3.70 & 2.22 \\
Asu River Group & 0.03 & 4.30 & 2.44 \\
Older Granite & 0.01 & 3.40 & 2.04 \\
Unidentified Basement Complex & & & 1.76 \\
\hline
\end{tabular}




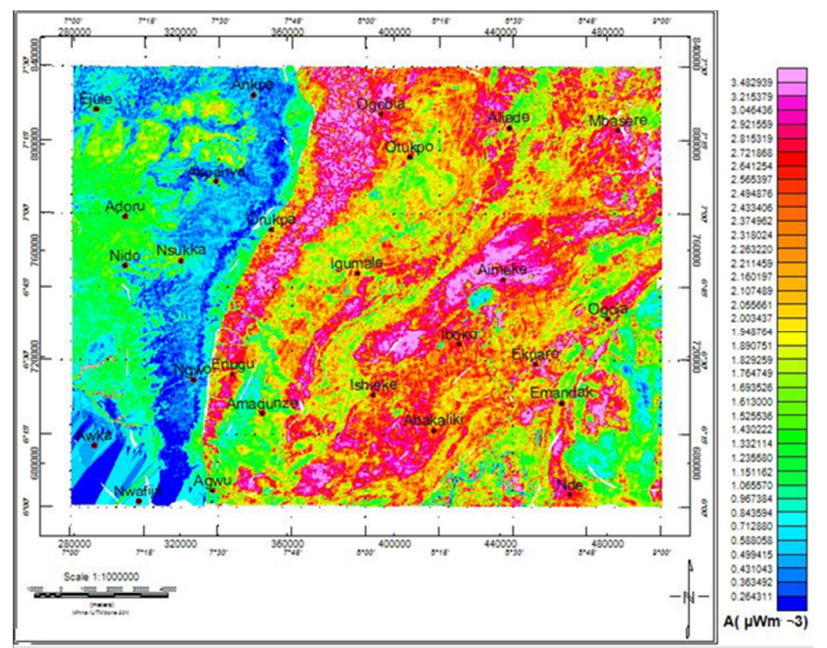

Fig 5: Radiogenic heat production map of the of the study area. $T$ he $\mathrm{x}-\mathrm{y}$-axes are longitude and latitude coordinates in decimal degrees.

\section{DISCUSSION OF RESULTS}

Generally, the radiogenic heat production varies greatly with rock type as outlined in this research. This explains the good correlation between the radiogenic heat production map shown in Figure 5 and the mapped geology in Figure 2. The average of the radiogenic heat production shows some similarity between the statistical characteristics of radiogenic heat production corresponding to Asata Nkporo Shale, Awgu Ndeaboh Shale Group, Eze Aku Shale Group and Asu River Group in Table 1, and shows an absolute similarity in their petrophysical properties (Salem et al., 2005). From the results, there is variation in the radiogenic heat values in rocks of the same type but in different locations, though, radiogenic heat production may reveal some irregularity due to the dissimilarity in the geochemical behaviour of $\mathrm{U}, \mathrm{Th}$, and $\mathrm{K}$ during the metamorphism process, which determines the distribution of the natural radio-elements (Salem et al., 2005). The area with high radiogenic heat production has high uranium content and this shows that the high heat is as a result of the abundance of uranium in this particular area. The values of the radiogenic heat range from 0.01 to $5.46 \mu \mathrm{Wm}^{-3}$ in the study area which is above $4 \mu \mathrm{Wm}^{-3}$ for a high radiogenic heat production (Alistair et al., 2014). The radiogenic heat values in Aimeke and Ogobia are well above the benchmark. These areas are considered hotspots because of the high values of radiogenic heat production.

Conclusion: Both qualitative and quantitative analysis showed high concentration of uranium, thorium and potassium in Aimeke and Ogobia areas. The high concentration of uranium, potassium and thorium in Aimeke and Ogobia shows high potentiality for geothermal energy and radiogenic heat production. These areas should be exploited for geothermal energy in order to increase the energy production in Nigeria. The production of geothermal energy from this area will put Nigeria on the list of countries that produce geothermal energy.

Acknowledgments: We sincerely thank all the staff of the department of Physics, University of Benin, Nigeria and Nigerian Geological Survey Agency, Abuja for their unlimited contribution to this study.

\section{REFERENCES}

Alistair, TM; Thomas, LH; Paul, LY; David, CW; Alan, JC (2014). Gamma-ray Spectrometry in Geothermal Exploration: State of the Art Techniques. Energies 2014, 7, 4757-4780; doi:10.3390/en7084757.

Bücker, C; Rybach, L (1996). A simple method to determine heat production from gamma-ray logs, Marine and Petroleum Geology 13, 373-375.

Fernández, M; Marzan, I; Correia, A; Ramalho, E (1998). Heat flow, heat production, and lithosphere thermal regime in the Iberian Peninsula, Tectonophysics 291, 29-53

Jessop, AM (1990). Thermal geophysics, Elsevier, Amsterdam.

Megwara, JU; Emmanuel, EU; Peter, IO; Mohammed, AD; Kolawole, ML (2012). Geothermal and Radioactive heat studies of part of southern Bida basin, Nigeria and the surrounding basement rocks.

Obaje, NG (2009). Geology and mineral resources of Nigeria. Berlin: Springer Publishers, pp. 1-203.

Ojoh, KA (1992). The Southern part of the Benue Trough (Nigeria) Cretaceous stratigraphy, basin analysis, paleo-oceanography and geodynamic 
evolution in the equatorial domain of the South Atlantic. NAPE Bull 7:131-152.

Petters, SW (1982) CentralWest African CretaceousTertiary benthic foraminifera and stratigraphy. Palaeontographica Abt A 179:1-104.

Rybach, L (1976). Radioactive heat production in rocks and its relation to other Petrophysical parameters, Pure and Appl. Geophysics. 114, 309-318.

Salem, A; Fairhead, D (2011). Geothermal reconnaissance of Gebel Duwi area, Northern Red Sea, Egypt using airborne magnetic and spectral gamma ray data. Getech pp.1-22.

Salem, A; Abouelhoda, E; Alaa, A; Atef, I; Sachio, E; Keisuke, U (2005). Mapping Radioactive Heat
Production from Airborne Spectral Gamma-Ray Data of Gebel Duwi Area, Egypt. Proceedings World Geothermal Congress, Antalya, turkey, 24-29.

Stacey, FD (1997). Physics of the Earth: New York, John Wiley and Sons, $2^{\text {nd }}$ ed., $414 p p$.

Telford, WM; Geldart, LP; Sherif, RE; Keys, DA (1990). Applied Geophysics. Cambridge: Cambridge University Press.

Thompson, PH; Judge, AS; Charbonneau, BW; Carson, JM; Thomas, MD (1996). Thermal regimes and diamond stability in the Archean Slave Province, Northwestern Canadian Shield, District of Mackenzie, Northwest Territories; in Current Research, 96-1E, Geological Survey of Canada, P. 135-146 